\title{
Secretion of momilactone A and B by the moss Hypnum plumaeforme
}

\author{
Hisashi Kato-Noguchi \\ Department of Applied Biological Science; Faculty of Agriculture; Kagawa University; Miki, Kagawa Japan
}

Key words: defense mechanism, growth inhibitor, momilactone, musci, pathogen, phytoalexin, rhizosphere

Nevertheless both plants are taxonomically quite distinct, momilactone A and B have been found only in rice and the moss, Hypnum plumaeforme which often forms large pure colonies. But biological meanings of momilactone $\mathrm{A}$ and $\mathrm{B}$ in $\mathrm{H}$. plumaeforme is unknown. UV-irradiation induced a 15- and 16-fold increase in the secretion level of momilactone $A$ and $B$, respectively, by $H$. plumaeforme into the growth medium. Jasmonic acid and the protein phosphatase inhibitor, cantharidin, also increased the momilactone A and B secretion levels by 12- to 15-fold. Cantharidin acts as an elicitor, jasmonic acid is an important signaling molecule regulating inducible defense genes against the pathogen infections. Therefore, elicitor and/or pathogen attacks may increase the secretion of momilactone $A$ and $B$. As momilactone $\mathrm{A}$ and $\mathrm{B}$ are phytoalexic and allelopathic, the increasing secretion of momilactone $A$ and $B$ may be associated with the activation of the defense responses of $H$. plumaeforme in the rhizosphere where plants must compete with invading root systems of neighboring plants and prevent from bacteria and fungi infections. Momilactone A and $\mathrm{B}$ may be able to prevent $H$. plumaeforme from pathogen infections and help competition with neighboring plants resulting in the formation of pure colonies.

Although rice and the moss Hypnum plumaeforme Wils are taxonomically quite distinct, momilactone $\mathrm{A}$ and $\mathrm{B}$ have so far been found only in rice and $H$. plumaeforme.$^{1-4}$ Momilactone A and B in rice plants are known to be synthesized as a part of defensive responses and exhibit antibacterial and antifungal activities. ${ }^{5-7}$ Rice plants were also found to secrete momilactone A and B from their roots into the rhizosphere and exhibit alleloapthic activities against weed plants. ${ }^{1,8-10}$ The plant rhizosphere is a densely populated area in which plant roots must compete with invading root systems of

Correspondence to: Hisashi Kato-Noguchi; Department of Applied Biological Science; Faculty of Agriculture; Kagawa University; Miki, Kagawa 761-0795 Japan; Fax: +81.87.891.3086; Email: hisashi@ag.kagawa-u.ac.jp

Submitted: 05/20/09; Accepted: 05/20/09

Previously published online as a Plant Signaling \& Behavior E-publication: http://www.landesbioscience.com/journals/psb/article/9080

Addendum to: Kato-Noguchi H, Kobayashi K. Jasmonic acid, protein phosphatase inhibitor, metals and UV-irradiation increased momilactone $A$ and $B$ concentrations in the moss Hypnum plumaeforme. J Plant Physiol 2009; 166:1118-22; PMID 19232772; DOI:10.1016/i.jplph.2008.12.012.

\section{Table 1 Effects of UV-irradiation, cantharidin and jasmonic acid on the secretion of momilactone $A$ and $B$ from $H$. plumaeforme}

\begin{tabular}{lcccc}
\hline & \multicolumn{4}{c}{ Secretion level $\left(\mu \mathrm{g} \mathrm{g}^{-1}\right.$ dry weight of $\boldsymbol{H}$. plumaeforme) } \\
& Control & UV-radiation & Cantharidin & Jasmonic acid \\
Momilactone A & $4.0 \pm 0.2$ & $61 \pm 5.2$ & $46 \pm 3.4$ & $59 \pm 4.7$ \\
Momilactone B & $6.3 \pm 0.2$ & $99 \pm 7.2$ & $74 \pm 6.1$ & $97 \pm 6.9$
\end{tabular}

H. plumaeforme was transplanted on $\mathrm{MS}$ growth medium and grown at $25^{\circ} \mathrm{C}$ with a 12-h photoperiod for 5 days as described previously. ${ }^{4}$ During the incubation, additional UV-irradiation ( 80 min par day, UV, emission peak $253 \mathrm{~nm} ; 10 \mu \mathrm{mol} \mathrm{m} \mathrm{m}^{-1}$ at plant level) was made. Momilactone $A$ and $B$ concentrations in the medium were then determined as the secretion levels by $H$. plumaeforme. For cantharidin- and jasmonic acid-treatments, H. plumaeforme was transplanted on MS growth medium containing 200 $\mu \mathrm{M}$ cantharidin or $100 \mu \mathrm{M}$ jasmonic acid, and grown at $25^{\circ} \mathrm{C}$ with a 12-h photoperiod for 5 days. All manipulations were carried out under sterile conditions. Control plants were incubated MS growth medium for 5 days. Means \pm SE from five independent experiments with five assays for each determination are shown.

neighboring plants for space, water and mineral nutrients, and with other soil-bore organisms including bacteria and fungi. ${ }^{11-14}$ Therefore, momilactone A and B probably play an important role in rice defense mechanism in the rhizosphere as antimicrobial and allelopathic agents. However, it has not clear that biological meanings of momilactone $\mathrm{A}$ and $\mathrm{B}$ in $H$. plumaeforme. H. plumaeforme is often dominative in plant communities and forms large pure colonies. ${ }^{15,16}$

H. plumaeforme was grown on MS growth medium and the concentrations of momilactone $\mathrm{A}$ and $\mathrm{B}$ in the medium were determined as the secretion levels of momilactone $A$ and $B$ from $H$. plumaeforme. The secretion levels of momilactone A and B were 4.0 and $6.3 \mu \mathrm{g} \mathrm{g}^{-1}$ dry weight of $H$. plumaeforme, respectively (Table 1). The endogenous concentration of momilactone $\mathrm{A}$ and $\mathrm{B}$ in $H$. plumaeforme was 58.7 and $23.4 \mu \mathrm{g} \mathrm{g}^{-1}$ dry weight, respectively. ${ }^{4}$ Thus, the secretion levels of momilactone $A$ and $B$, respectively, were 6.8 and $27 \%$ of momilactone $A$ and $B$ concentrations in $H$. plumaeforme. Therefore, although the endogenous concentration of momilactone $\mathrm{A}$ in $H$. plumaeforme was greater than that of momilactone $\mathrm{B}$, the secretion level of momilactone $\mathrm{B}$ was much greater than that of momilactone $A$, which suggests that momilactone B may be selectively secreted into the medium than momilactone $\mathrm{A}$. In addition, biological activity of momilactone $\mathrm{B}$ was much greater than that of momilactone A. ${ }^{10}$ 
UV-irradiation (80 min-irradiation per day for 5 days, UV: emission peak $253 \mathrm{~nm} ; 10 \mu \mathrm{mol} \mathrm{m}^{-1} \mathrm{~s}^{-1}$ at plant level) increased the secretion levels of momilactone A and B by 15- and 16-fold, respectively (Table 1). The concentrations of momilactone $A$ and B in UV-irradiated $H$. plumaeforme were 786 and $348 \mu \mathrm{g} \mathrm{g}^{-1}$ dry weight, respectively. ${ }^{4}$

Jasmonic acid and cantharidin increased the secretion of momilactone $\mathrm{A}$ and $\mathrm{B}$ by $H$. plumaeforme (Table 1$)$. The concentrations of momilactone $\mathrm{A}$ and $\mathrm{B}$, respectively, were 796 and $345 \mu \mathrm{g} \mathrm{g}^{-1}$ dry weight in $100 \mu \mathrm{M}$ jasmonic acid-treated $H$. plumaeforme, and 661 and $282 \mu \mathrm{g} \mathrm{g}^{-1}$ dry weight in $200 \mu \mathrm{M}$ cantharidin-treated $H$. plumaeforme. ${ }^{4}$ Cantharidin is the protein serine/threonine phosphatase inhibitor, and has been shown to mimic elicitor action and activate defense responses of plants against pathogen attacks. ${ }^{17,18}$ Jasmonic acid is an important signaling molecule in plants for the activation of defense mechanisms in response to wounding, herbivores and pathogen attacks. ${ }^{19-21}$ Therefore, these results indicate that elicitor and/or pathogen attacks may also increase the production of momilactone $\mathrm{A}$ and $\mathrm{B}$ in $H$. plumaeforme and the secretion of momilactone $\mathrm{A}$ and $\mathrm{B}$. In addition, the endogenous concentrations of momilactone $\mathrm{A}$ in jasmonic acid- and cantharidin-treated $H$. plumaeforme were greater than those of momilactone $\mathrm{B}$, but the secretion levels of momilactone $\mathrm{B}$ was much greater than that of momilactone A.

The ratio of momilactone A to momilactone B in control, UV-irradiated, and jasmonic acid- and cantharidin-treated H. plumaeforme was 2.5 (control), 2.4 (UV-irradiation), 2.3 (cantharidin-treatment) and 2.3 (jasmonic acid-treatment). Thus, UV-irradiation, and jasmonic acid- and cantharidin-treatments increased the endogenous concentrations of momilactone $\mathrm{A}$ and $\mathrm{B}$ but did not alter the momilactone $\mathrm{A}$ and $\mathrm{B}$ ratio, which suggest that the production of momilactone $\mathrm{A}$ and $\mathrm{B}$ in $H$. plumaeforme may be increased by these treatments due to the induction of the biosynthesis prior to the branch point of momilactone A and B biosynthetic pathway. It was found in rice that UV-irradiation increased induction of gene OsCyc1 encoding syn-copalyl diphosphate synthase which catalyzes the reaction from geranylgeranyl diphosphate to syn-copalyl diphosphate. This reaction is prior to the branch point of momilactone $\mathrm{A}$ and B biosynthesis (Otomo et al. 2004). ${ }^{22}$ In higher plants, UV-irradiation leads to the induction of a range of genes involved in pathogenesis-related proteins, and to the increase in jasmonic acid and/or salicylic acid levels. ${ }^{23}$ Therefore, the increases in momilactone $\mathrm{A}$ and $\mathrm{B}$ in $H$. plumaeforme by $\mathrm{UV}$-irradiation might be caused by UV-induced increase of unknown jasmomic acid-like substances.

The secretion level of momilactone B was 1.6- (control), 1.6- (UV irradiation), 1.7- (cantharidin-treatment) and 1.6-fold (jasmonic acid-treatment) greater than the respective secretion level of momilactone A (Table 1). Thus, UV-irradiation, and jasmonic acid- and cantharidin-treatments increased the secretion levels of momilactone $\mathrm{A}$ and $\mathrm{B}$, but did not change the ratio of the secretion level of momilactone A and B. Although mechanisms of the exudation are not well understood, it is suggested that plants are able to secrete a wide variety of compounds from root cells by plasmalemma-derived exudation, endoplasmic-derived exudation, and proton-pumping mechanisms. ${ }^{12,13}$ Through the root exudation of compounds, plants are able to regulate the soil microbial community in their immediate vicinity, change the chemical and physical properties of the soil, and inhibit the growth of competing plant species. ${ }^{11-14}$

Momilactone A and B were reported to have antimicrobial activities ${ }^{6,7,22}$ and alleloapthic activities. ${ }^{1,8-10}$ Therefore, the increasing secretion of momilactone $\mathrm{A}$ and $\mathrm{B}$ may be associated with the activation of the defense responses of $H$. plumaeforme against pathogens and competitive neighboring plants. The secretion of momilactone $\mathrm{A}$ and $\mathrm{B}$ into the rhizosphere may provide a competitive advantage for $H$. plumaeforme to form pure colony through the prevention of bacteria and fungi infections and the growth inhibition of competitive plant species. However, the involvement of momilactone B for the defense mechanism may be greater than momilactone A because growth inhibitory activity and secretion level of momilactone B were grater than those of momilactone A.

\section{References}

1. Kato-Noguchi H. Allelopathic substance in rice root exudates: Rediscovery of momilactone B as an allelochemical. J Plant Physiol 2004; 161:271-6.

2. Kobayashi K, Shigemori H, Kato-Noguchi H. Allelopathic potential of Hypnum plumaeforme $\mathrm{L}$. and its allelopathic substances. In: The proceedings of the $4^{\text {th }}$ Asia-Pacific Conference on Chemical Ecology, from Biomolecules to Ecosystems an Interactive Chemical Message for our Future, Tsukuba, Japan, 77.

3. Nozaki H, Hayashi KI, Nishimura N, Kawaide H, Matsuo A, Takaoka D. Momilactone $\mathrm{A}$ and $\mathrm{B}$ as allelochemicals from moss Hypnum plumaeforme: First occurrence in bryophytes. Biosci Biotech Biochem 2007; 71:3127-30.

4. Kato-Noguchi H, Kobayashi K. Jasmonic acid, protein phosphatase inhibitor, metals and UV-irradiation increased momilactone A and B concentrations in the moss Hypnum plumaeforme. J Plant Physiol 2009; 166:1118-22.

5. Tamogami S, Kodama O. Coronatine elicits phytoalexin production in rice leaves (Oryza sativa L.) in the same manner as jasmonic acid. Phytochemistry 2000; 54:689-94.

6. Jung Y-H, Lee J-H, Agrawal GK, Rakwal R, Kim J-A, Shim J-K, et al. The rice (Oryza sativa) blast lesion mimic mutant, blm, may confer resistance to blast pathogens by triggering multiple defense-associated signaling pathways. Plant Physiol Biochem 2005; 43:397-406

7. Okada A, Shimizu T, Okada K, Kuzuyama T, Koga J, Shibuya N, et al. Elicitor induced activation of the methylerythritol phosphate pathway toward phytoalexins biosynthesis in rice. Plant Mol Biol 2007; 65:177-87.

8. Kato-Noguchi H, Ino T, Sata N, Yamamura S. Isolation and identification of a potent allelopathic substance in rice root exudates. Physiol Plant 2002; 115:401-5.

9. Kong C, Liang W, Xu X, Hu F. Release and activity of allelochemicals from allelopthic rice seedlings. J Agri Food Chem 2004; 52:2861-5.

10. Kato-Noguchi H, Ota K, Ino T. Release of momilactone A and B from rice plants into the rhizosphere and its bioactivities. Allelopathy J 2008; 22:321-8.

11. McCully E. Roots in soil: unearthing the complexities of roots and their rhizospheres. Annu Rev Plant Physiol Plant Mol Biol 1999; 50:695-718.

12. Hawes MC, Gunawardena U, Miyasaka S, Zhao X. The role of root border cells in plant defense. Trends Plant Sci 2000; 5:128-33.

13. Bais HP, Park S-W, Weir TL, Callaway RM, Vivanco JM. How plants communicate using the underground information superhighway. Trends Plant Sci 2004; 9:26-32.

14. Belz RG. Allelopathy in crop/weed interactions_an update. Pest Manag Sci 2007; 63:308-26.

15. Ando H, Matsuo A. Applied bryology. In: Cramer J, ed. Advance Bryology, Vol 2. Berlin: International Association of Bryologists 1984; 133-229.

16. Tsubota H, Kuroda A, Masuzaki H, Nakahara M, Deguchi H. Preliminary study on allelopathic activity of bryophytes under laboratory conditions using the sandwich method. J Hattori Bot Lab 2006; 100:517-25.

17. MacKintosh C, Lyon GD, MacKintosh RW. Protein phosphatase inhibitors activate anti-fungal defence responses of soybean cotyledons and cell cultures. Plant J 1994; 5:137-47.

18. Rakwal R, Shii K, Agrawaland GK, Yonekura M. Protein phosphatase inhibitors activate defense responses in rice (Oryza sativa) leaves. Physiol Plant 2001; 111:151-7.

19. Glazebrook J. Contrasting mechanisms of defense against biotrophic and necrotrophic pathogens. Annu Rev Phytopathol 2005; 43:205-27. 
Momilactone in secretory fluid of moss

20. Peña-Cortés H, Barrios P, Dorta F, Polanco V, Sánchez C, Sánchez E, Ramírez I. Involvement of jasmonic acid and derivatives in plant response to pathogen and insects and in fruit ripening. J Plant Grow Regul 2005; 23:246-60.

21. Halim VA, Vess A, Scheel D, Rosahl S. The role of salicylic acid and jasmonic acid in pathogen defence. Plant Biol 2006; 8:307-13.

22. Otomo K, Kenmoku H, Oikawa H, König WA, Toshima H, Mitsuhashi W, et al. Biological functions of ent-and syn-copalyl diphosphate synthases in rice: key enzymes for the branch point of gibberellin and phytoalexin biosynthesis. Plant J 2004; 39:886-93.

23. Mackerness SAH. Plant responses to ultraviolet-B (UV-B: $280-320 \mathrm{~nm}$ ) stress: What are the key regulators? Plant Grow Regu 2000; 32:27-39. 